\title{
Fordítás és tolmácsolás \\ a digitális korban
}

\author{
Horváth Ildikó \\ E-mail:horvath.ildiko@btk.elte.hu
}

\begin{abstract}
Kivonat: A technológiai fejlődés mind a fordítási mind a tolmácsolási piacon érezteti hatását: az új információs és kommunikációs technológiák megjelentek és elterjedtek. A digitális forradalom következtében a hagyományos értelemben vett hivatásos fordítás és tolmácsolás átalakult. A mostani gyorsan változó időkben mélyreható változások tapasztalhatók a piacon a munkakörnyezetben, a munkakörülményekben és a folyamatokban, valamint a nyelvi közvetítők tevékenységében, a fordítási folyamatban elvégzendő feladatokban és a nyelvi közvetítők által betöltött szerepekben. A jelen tanulmányban a legfontosabb változásokat mutatjuk be, majd a fordítás és tolmácsolás területén tapasztalható fejleményeket vázoljuk fel.

Kulcsszavak: nyelvi közvetítés, nyelvi ipar, neurális gépi fordítás (NMT), ember által támogatott fordítás (HAT), MI-tolmács, tolmácsolási terminológiamenedzsment szoftverek és platformok
\end{abstract}

\section{Bevezetés: nyelvi közvetítés, transzkulturális kommunikáció és a digitális kor}

A nyelvi közvetítés olyan átfogó kifejezés, amely adott szöveg vagy beszéd forrásnyelvről a célnyelvre való átültetésének különböző fajtáit öleli fel. Hagyományos értelemben véve írásbeli és szóbeli nyelvi közvetítésről, azaz fordításról és tolmácsolásról beszélünk. Mindazonáltal, a nyelvi közvetítésnek létezik ún. „hibrid” módja is (Felekné Csizmazia 2014; Horváth 2013; Parkin 2010), mint például a blattolás, ami írott forrásnyelvi szöveg azonnali hangzó szöveggé való alakítását jelenti. A jelnyelvi tolmácsolás pedig „,bimodális” tolmácsolási módnak tekinthető (Corina és Vaid 1994). A technológiai fejlődés mind a fordítási mind a tolmácsolási piacon érezteti hatását (Horváth 2015a). Továbbá, az új infokommunikációs technológiáknak (IKT) a nyelvi közvetítés piacán való megjelenésével és széles körben való elterjedésével olyan új szakmák is kialakultak, mint pl. az audiovizuá-

Hivatkozás: Horváth I. 2020. Fordítás és tolmácsolás a digitális korban. Forditástudomány 22. évf. 1. szám. 5-16. DOI: https://doi.org/10.35924/fordtud.22.1.1 
lis fordítás területén a „respeaking” (Szarkowska et al. 2018), vagy a gépi fordítások előszerkesztése és utószerkesztése (Varga 2015).

Az interkulturális kommunikáció az 1980-as és 90-es években vált aktuális témává a fordítástudományban a globalizáció és az ún. globális falu térnyerésével (Samovar és Porter 1997). Ezzel egy időben a fordítás- és tolmácsolástudomány művelői a fordítást és a tolmácsolást egyre gyakrabban definiálták az interkulturális kommunikáció egyik válfajaként (Bassnett 1991; Katan 2000). Ez azt jelentette, hogy a nyelvi közvetítés folyamata nem csak a nyelvek, hanem a kulturális keretek megértésén alapszik, és a kultúrák közötti közvetítést is szükségessé tesz. A digitális kor egy közelmúltbeli hozadéka, hogy az interkulturalitás fogalmát felváltotta a transzkulturalitás fogalma. Tehát a modern fordítástudományra és a modern nyelvi közvetítésre már inkább illik a transzkulturális, a kultúrákon átívelő kommunikáció fogalma (Schippel 2012; Hepp 2015).

A mai kort gyakran hívjuk digitális kornak vagy korszaknak. A Cambridge English Dictionary szerint a digitális korszak olyan időszak, amelyben ,az információk többsége digitális formában érhető el" (saját fordítás) ${ }^{1}$. Ennek a kornak a jellemzője, hogy a digitális technológia az élet minden területén jelen van, az IKT-k elterjedése megváltoztatta azt, ahogy élünk, dolgozunk, a szabadidőnket töltjük és kommunikálunk. Az IKT-k hatása az gyógyítástól az oktatáson keresztül a mezőgazdaságig számos szakmán érezhető.

A globalizáció és az IKT-k elterjedése az élet minden területére, a digitális tartalmak és információ azt eredményezte, hogy ma már egy „összekapcsolt”, behálózott világban élünk. Ezenfelül, a digitális interakciók nagy része ma már felhőalapú. A Translation in the Digital Age címü nagyhatású müvében Cronin (2013) azt állítja, hogy az információs társadalom mára már interakciós társadalommá vált, valamint, hogy a digitális korra is egyre inkább igaz, hogy interakciós korrá válik.

A fent felsorolt változások igen nagy hatást gyakoroltak a nyelvi közvetítésre. A hagyományosan fordításnak és tolmácsolásnak nevezett szakmákat a digitális forradalom alaposan átalakította. A mostani gyorsan változó időkben mélyreható változások tapasztalhatók a piacon, a munkakörnyezetben, a munkakörülményekben és a folyamatokban, valamint a nyelvi közvetítők tevékenységében, a fordítási folyamatban elvégzett feladatokban és az általuk beöltött szerepekben. A továbbiakban a legfontosabb változásokat mutatjuk be, majd a fordítás és tolmácsolás területén tapasztalható fejleményeket vázoljuk fel.

\section{A nyelvi ipar}

A fenitek egyik következménye a globális nyelvi ipar kialakulása. A LIND (Language Industry) Szakértői Csoport feladata, hogy az Európai Bizottság Fordítási

\footnotetext{
${ }^{1}$ https://dictionary.cambridge.org/dictionary/english/digital-age
} 
Föigazgatóságának szakmai információkat nyújtson a nyelvi iparral kapcsolatban. A LIND meghatározása szerint a nyelvi ipar a következő foglalkozásokat öleli fel: fordítás, tolmácsolás, filmfeliratozás és filmszinkronizálás, nyelvi ipari eszközök fejlesztése, nemzetközi konferenciaszervezés, nyelvtanítás és nyelvi tanácsadás².

A nyelvi ,ipar” kifejezés egy bizonyos méretre is utal. A The size of the language industry in the EU címü, 2009-ben publikált tanulmány becslése szerint az EU-tagállamokban a nyelvi ipar 8,4 milliárd eurót tett ki 2008-ban (Rinsche és Portera-Zanotti 2009). Ebbe az értékbe a fordítás, a tolmácsolás, a szoftverlokalizáció és a weboldal-globalizáció, nyelvtechnológiai eszközök fejlesztése, nyelvtanítás, nyelvi tanácsadás és többnyelvű nemzetközi konferenciák szervezése tartozik. Ebből a fordítás és tolmácsolás szelet - amelybe beleszámít a szoftverlokalizáció és a weboldal-globalizáció is - becsült értéke 5,7 milliárd euró volt 2008-ban.

Ugyanez a tanulmány 10\%-os összetett éves növekedéssel számolva a nyelvi ipar értékét 2015-re 16,65 milliárd euróra becsülte. Egy ennél frissebb tanulmány a 2019-es Language Industry Survey. Eszerint az Európai Unióban a nyelvi ipar piacán a globális fordítási tevékenységgel foglalkozó vállalatok és az egyéni szakemberek további növekedésre számíthatnak. Sőt ez e tendencia még fel is gyorsul. A válaszadó vállalkozások $69 \%$-a további növekedésre számít, míg csupán 5\%-uk számol a fordítási tevékenység csökkenésével. A nyelvi iparnak ez a növekedése egyértelmüen összhangban van azzal a bövüléssel, amelyről a válaszadó vállalkozások 2014 óta folyamatosan beszámolnak. A globális nyelvi ipar méretéről készült egyik legismertebb felmérés a CSA Research által publikált Annual Review of the Services and Technology Industry that Supports Translation, Localization, and Interpreting. A 2018-as Language Services Market Review 46,52 milliárd USD értékü piacról számol be. Ez a jelentés is további növekedést jelez elöre, miszerint 2021-re a piac értéke 56,18 milliárd USD dollárt tesz ki. Cronin (2013) szerint is ,a modern világban a fordítás iránti igény folyamatosan nö" (Cronin 2013: 10, saját fordítás). Mindezek értelmében elmondható, hogy a nyelvi és fordítási ipar jelenlegi és jövőbeli helyzetére vonatkozó becslések és előrejelzések meglehetősen pozitív képet mutatnak.

Az ,ipar” kifejezés a méreten kívül egy bizonyos jellegre és struktúrára is utal. A nyelvi piac és ezen belül a fordítás és tolmácsolás globalizált nyelvi szolgáltatásokká váltak, ahol a megbízó tartózkodási helyéhez való közelség már nem követelmény. Ez korunk egyik vívmánya. A modern fordítók gyakran online projektekben dolgoznak, és különböző szerepeket töltenek be, különböző feladatokat látnak el (fordítás, többnyelvü terminológia, lektorálás stb.). Együttmüködésre alapuló csapatmunkában dolgoznak, amihez magas szintü interperszonális készségekre van szükség. Osztoznak a nekik szánt feladat eredményében, és hozzájárulnak a projekt sikeréhez.

\footnotetext{
${ }^{2}$ https://ec.europa.eu/info/departments/translation/language-industry-platform-lind_en
} 
Az a tény, hogy a fordítói projekteket igen gyakran csapatmunkaként szervezik, új megvilágításba helyezi a fordítókat érintő egyik legkorábbi és legtöbbet vitatott jogi kérdést, a szakfordítások szellemi tulajdonának és szerzői jogának a kérdését is. A szellemi tulajdon védelmének elveit az Irodalmi és a müvészeti müvek védelméröl szóló Berni Egyezmény már 1886-ban lefektette ${ }^{3}$. Ez az egyezmény a fordításokat alkotómunka eredményének tekinti (Esteves 2005), így azokat szellemi tulajdonjog-védelem illeti meg (lásd még Translation and intellectual property rights. Final report - Study 2014). Ennek ellenére még a múfordítók számára is nehézséget jelent jogaik érvényesítése (Esteves 2005). Más szerzők is amellett érvelnek, hogy a szellemi tulajdonjog-védelem tekintetében a fordítókra nagyobb figyelmet kellene fordítani (lásd Basalamah 2001; Venuti 1998). Az együttmüködésen alapuló csapatmunkában lefordított szövegek esetében, amikor a végtermék közös munka és több lektorált verzió eredményeképpen készül el, a szellemi tulajdon és a szerzői jogok kérdése már veszíteni látszik létjogosultságából.

A fordítói szolgáltatói piacot jellemző folyamatos keresletnövekedés nemcsak azt eredményezte, hogy a fordítások elkészítését csapatmunkában oldották meg, hanem azt is, hogy ezeket a szolgáltatásokat egyre gyorsabban kell elvégezni. Mindez azoknak az technológiai újításoknak köszönhetően teljesíthetö, mint pl. a fordítást segítő szoftverek vagy a terminológiai adatbázisok (lásd lentebb). Egy további követelmény a szolgáltatás kiváló minősége, ami a megbízók számára a legfontosabb tényező, majd ezt követi a harmadik helyen a szolgáltatott termék minősége (2019 Language Industry Survey). Ezzel egy időben megfigyelhető az ún. kommodifikáció folyamata, ami egy viszonylag új jelenség a fordítási szolgáltatói piacon. A kommodifikáció, azaz az áruvá válás folyamata jelen esetben azt jelenti, hogy talán a műfordítás és az audiovizuális fordítás kivételével, az írásbeli nyelvi közvetítés már nem annyira számít elsősorban intellektuális tevékenységnek. Ehelyett a fordítások olyan ipari termékekké váltak, amelyeket a nyelvi piacon adnak el, ahol a profitmaximalizálás és árnyomás gyakori tényezők. A 2019-es Language Industry Survey szerint „minden válaszadói csoport [vállalkozások, egyéni fordítók, fordítói szolgálatok és képzőintézmények] véleménye szerint az árnyomás a legfontosabb negatív trend" (saját fordítás).

\section{HAT helyett HAT}

A digitális korban dolgozó fordítónak egyre kevesebb idő alatt kell jó minőségű munkát végeznie, és egyre nagyobb mennyiségü szöveg fordítását kell elvégeznie. Ezeknek az első látásra egymásnak ellentmondó követelményeknek a technológiai fejlesztéseknek és a globalizációnak köszönhetően tudnak megfelelni. Ugyanis egyrészt felhő alapú online csapatokban el tudják egymást között osztani a munkát

${ }^{3}$ https://www.wipo.int/treaties/en/text.jsp?file_id=283698 
és ki tudják szabni a feladatokat, másrészt pedig számos olyan számítógépes eszköz áll a rendelkezésükre, amelyek mindezt lehetővé teszik. A CAT (számítógéppel támogatott fordítás) kifejezés az 1990-es években, a személyi számítógépek elterjedésével jelent meg. Ekkor a fordítók munkakörnyezete alapjaiban változott meg: a fordítók ugyanis korábban tollat majd írógépet és papír alapú szótárt használtak a fordításhoz, valamint könyvtárba mentek vagy a fordítandó szöveg témájában jártas szakemberhez fordultak terminológiai segítségért. A megjelenésükkor a CAT-eszközök gyakorlatilag a személyi számítógépet és a szövegszerkesztő szoftvert jelentették. Később a CAT szélesebb fogalommá vált, és már minden olyan eszközt értettünk rajta, amely a fordítót a fordítás során segíti (Zetzsche 2008 in Ábrányi 2015). Ezek a terminológiakezelö eszközök, a korpuszelemző eszközök, vagy a szövegszerkesztő és helyesírásellenőrző programok, online vagy offline szótárak, szószedetek, referenciaanyagok, nyelvtani segédeszközök, párhuzamos szövegek, OCR (optikai karakterolvasó) vagy DTP (asztali kiadványszerkesztő) programok, valamint projektmenedzsment és adminisztrációs eszközök (Bowker 2002; Craciunescu et al. 2004 in Ábrányi 2015).

A CAT-eszközök egy kisebb csoportját fordítási környezetnek hívjuk (TEnTtranslation environment tools). Ez a kifejezés ,,azokat a szoftvereket jelöli, amelyek központi komponense a fordítómemória, ezenfelül pedig számos további funkciót is integrálnak, például terminológiakezelőt, szövegpárhuzamosítót vagy elemzést" (Ábrányi 2015: 147). Ezek az eszközök egyrészt növelik a produktivitást, másrészt segítségükkel ,a terminológia és a stílus szintjén nagyobb fokú konzisztencia érhető el" (Ábrányi 1915: 153), így a minőség is javul.

A fordítói szakmában bekövetkezett egyik legújabb változás, hogy az automatizált gépi fordítás megjelenésével a CAT-et (amikor a számítógép támogatja az embert) felváltotta a HAT, (human-assisted translation, vagyis, amikor az ember támogatja a gépet). Ez egy alapvető szemléletváltást jelentett. A gépi fordítás egyébként nem új jelenség, hiszen már mintegy 50 éve velünk van, és érdemes arra felhívni a figyelmet, hogy a fordítástudomány sem a közelmúltban kezdett el vele foglalkozni (pl. Bar-Hillel 1951; Hutchins 1986; Lawson 1981; Sager 1994; Somers 1998; Vauquois 1976). A gépi fordítás eddig három fejlődési szakaszon ment át: (1) a szabály alapú, (2) a statisztikai és (3) a neurális hálózatokon alapuló (NMT) gépi fordítás. Az újdonság abban áll, hogy úgy tünik az NMT áttörést hozott, mivel jelentősen jobb minőségű célnyelvi szövegeket állít elő a korábbi rendszereknél. Az NMT-t támogató technológiák alapja többek között a „,big data” és a mesterséges intelligencia (MI). A gépi fordítás ezen fejlődését jól tükrözi az Európai Bizottság Fordítási Főigazgatóságának a gyakorlata, ahol a három fő szakasz a következö: (1) EC Systran/ECMT körülbelül 1976-2010 között; (2) MT@EC 2013-2018; (3) eTranslate 2018-től kezdődően (Rummel 2019).

Az automatizált fordítói rendszerek elterjedését a fordítói piacon jellemző növekvő kereslet vezérli (Mileto 2011; Taravella és Villeneuve 2013; 2018 Language Services Market Review; 2019 Language Industry Survey), amelyet a fordítási szakemberek hiánya miatt nem lehet a gépek nélkül kielégíteni (Taravella és Vil- 
leneuve 2013). Ezzel egyi időben az EMT (European Masters in Translation) program új kompetenciakerete szerint a fordítóképző programok felé ma már elvárás, hogy a képzésbe bevegyék a gépi fordítást. A cél, hogy a fordító mesterképzésben végzett hallgatók munkavállalási lehetőségeit növeljék, ezért a keretrendszerben nagy hangsúlyt kap a gépi fordítás és az automatizált fordításhoz kapcsolódó készségek, mint pl. az elöszerkesztés vagy az utószerkesztés, továbbá a gépi fordítás alapjaink az elsajátítása, a gépi fordításnak a fordítási folyamatra gyakorolt hatása, a gépi fordítói rendszerek helye a fordítási munkafolyamtokban, a gépi fordítói rendszerek megfelelő alkalmazása (EMT Competence Framework - 2017). Mindez igen jelentős változás a korábbi, 2009-es EMT kompetenciakerethez képest, amikor is a fordító mesterszakos hallgatóknak még csak a gépi fordítás által nyújtott lehetőségekkel, és a gépi fordítás korlátaival kellett tisztában lenniük (Gambier et al. 2009).

\section{4. Új feladatok és szerepek}

A technológiai fejlődés által elöidézett változások következtében a nyelvi közvetítők által ellátandó új feladatok és szerepek alakultak ki. A nyelvi közvetítőket ma már LSP-nek (language service provider, nyelvi szolgáltató) hívjuk, ami szintén egy szemléletváltást jelöl. Az LSP kifejezés használata nem mindig egyértelmü, hiszen egyszerre jelentheti az egyéni fordítókat/tolmácsokat és a fordítást/tolmácsolást közvetítő irodákat is. Mindazonáltal jól kifejezi azt a tényt, hogy manapság „már a fordító és tolmács elsődleges feladata nem csak maga az írásbeli vagy szóbeli nyelvi közvetítés: a fordítók és tolmácsok ma már komplex szolgáltatást nyújtanak" (Horváth 2015a: 7).

Az LSP-k a fordításon kívül gyakran más feladatokat is el kell, hogy lássanak: terminológusként, lektorként, nyelvi tanácsadóként dolgoznak, vagy éppen lokalizációs feladatokat, előszerkesztést vagy utószerkesztést végeznek. Továbbá új szakmák is megjelentek a piacon, mint például a fordítási projektmenedzser, vendormenedzser, nyelvi mérnök vagy fordítói kiadványszerkesztő (DTP) szakember (Horváth 2015c).

\section{5. Új technológiák és tolmácsolás}

A fordítással kapcsolatos változások után a továbbiakban azokat a fejleményeket tekintjük át, amelyeket az új információs és kommunikációs eszközök elterjedése a tolmácsolási piacon hozott. Elöször is megállapítható, hogy a tolmácsok a tolmácsolási megbízásra való felkészüléshez számos ilyen eszközt használnak. Továbbá a „digitális kabin” kifejezést is egyre gyakrabban hallhatjuk a szakmában. A digitális kabin azt jelenti, hogy az olyan elektronikus eszközök, mint pl. a laptop, a tablet vagy az iPad a tolmács mindennapos munkaeszközeivé váltak, amelyeket a 
munkavégzés során rendszeresen használ. Ez utóbbi elsősorban szinkrontolmácsolás esetén megvalósítható. Ezeket az eszközöket a tolmács nem csak a megbízásra való felkészülésnél, hanem a tolmácsolás során is segítségül hívja pl. az elöre vagy a tolmácsolás helyszínén rendelkezésére bocsátott ppt előadások kivetítésére, vagy arra, hogy olyan ismeretlen terminusokat és kifejezéseket keressen valós időben, amelyek nem képezik mentális lexikonja éppen aktivált részét.

A tolmácsolási piacon továbbá az olyan technológiai fejlesztések, mint a távtolmácsolás, a számítógéppel támogatott tolmácsolás (CAI, computer-assisted interpreting) vagy az automatizált gépi tolmácsolás is teret nyer. Távtolmácsolásról akkor beszélünk, amikor a tolmács nem abban a teremben dolgozik, ahol a tolmácsolási esemény zajlik. Ez jelentheti azt, hogy egy másik teremben, de ugyanazon a helyszínen tartózkodik, de azt is, hogy egy teljesen másik helyszínen, városban vagy országban (Braun 2015; Moser-Mercer 2005; Mouzourakis 2010). A távtolmácsolásnak több fajtája létezik: telefonos tolmácsolás, vagy videokonferencia által létrejött tolmácsolás konszekutív vagy szinkron módban. Fantinuoli ezt és a digitális kabinban elérhető technológiát „helyzet-orientált technológiának” (setting-oriented technology) nevezi, ami nem más, mint ,,a tolmácsolási folyamat körül fellelhető IKT-eszközök és szoftver" (Fantinuoli 2017a: 156, saját fordítás).

A számítógéppel támogatott tolmácsolás a közelmúlt egyik fejlesztése, amely jelenleg a tolmácsolási piacon terjedőben van. Fantinuoli (2017a) meghatározása szerint a számítógéppel támogatott tolmácsolási eszközök olyan folyamatorientált technológiák, amelyek magukban foglalják ,többek között a terminológiamenedzsment rendszereket, tudáskinyerési szoftvereket, korpuszelemző eszközöket”. Az teszi ezeket az eszközöket folyamat-orientálttá, hogy „,céljuk, hogy a tolmácsot a tolmácsolás egyes alfolyamatai során és a tolmácsolási megbízás különböző szakaszaiban segítsék [...] a tolmácsolási módtól függetlenül” (Fantinuoli 2017a: 156, saját fordítás). Ezenfelül még más, olyan eszköz is elérhető már, mint például a közelmúltban kifejlesztett tolmácsolási glosszáriumkezelő szoftverek ${ }^{4}$ (Costa et al. 2014; Fantinuoli 2017b). Az ilyen szoftverek célja, hogy a tolmácsolás során a terminológiai munkát megkönnyítsék azáltal, hogy a forrás- és célnyelven megjelenítik a kulcsszavakat, a tulajdonneveket és a számokat. Ezeket az szoftvereket a tolmácsok egyelöre nem használják gyakran (Riccardi et al. 2019). Érdemes még itt megjegyezni, hogy eddig hiányoznak azok a tudományos kutatások, amelyek azt vizsgálnák, hogy vajon a tolmácsolás során egy ilyen szoftver használata esetleg túl nagy kognitív terhet jelent-e a konferenciatolmács számára (lásd Gile 2009).

\footnotetext{
${ }^{4}$ Riccardi et al. (2019) az alábbi szoftvereket gyüjtötte össze: InterpretBank (http://www. interpretbank.com/); Intragloss (http://intragloss.com/); Interplex (http://www.fourwillows.com/interplex.html); LookUp (http://www.lookup-web.de/); Terminus (http://www. wintringham.ch/cgi/ayawp.pl/t/terminus); Interpreter's help (https://interpretershelp. com/)
} 
Az elmúlt néhány évben a szinkrontolmácsolásra is alkalmas, szoftver-alapú ún. tolmácsolási platformok fejlesztői is próbálnak betörni a tolmácsolási piacra. Ezek a platformok távtolmácsolással lehetővé teszik, hogy akár egy többnyelvü konferencia több tagból álló tolmácscsapata a világ különböző részéröl jelentkezzen be, és végezze a tolmácsolást otthonról, vagy egy ún. erre a célra kialakított speciális központból (hub). A szakma részéről ez egyik első, ebben a témában végzett átfogó felmérést az Európai Bizottság Tolmácsolási Föigazgatósága (DG SCIC) végezte. A felmérés legfontosabb konklúziója szerint a jelenleg rendelkezésre álló tolmácsplatformok még számos kívánnivalót hagynak maguk után a hangminőség, a képminőség, az tolmácsinterfész, a mikrofon átadásának módja tekintetében (European Commission, DG SCIC 2019).

A neurális gépi fordítás elterjedését követően, a tolmácsolás terén a legújabb fejlemény, hogy a nagyobb technológiai cégek elkezdték elkezdtek foglalkozni az ún. MI-tolmács kifejlesztésével „,big data” használatával. Ezek a próbálkozások eddig még csekély sikerrel jártak ${ }^{5}$. Jóllehet a teljesen automatizált gépi tolmácsot még nem sikerült kifejleszteni, léteznek már olyan gépi konszekutív és szinkrontolmács eszközök, amelyek célja különböző nyelvet beszélő kommunikációs partnerek közötti nyelvi szakadék áthidalása. Ezek „közös jellemzője, hogy korlátozott számú, egy konkrét kommunikációs helyzetben tipikusan a leggyakrabban elhangzó, elöre betáplált kifejezéseket, kérdéseket tolmácsolnak különböző nyelvek között. Ilyen kontextus például az utazás, a humanitárius küldetések, az orvosi ellátás, egyetemi előadások, a háborúk, melyek során nem mindig elérhető nem gépi tolmács" (Horváth 2016b: 167).

\section{6. Összefoglalás}

A technológiai fejlödés és az új IKT-k hatása érezhető a fordítók és tolmácsok mindennapjaiban, valamint elterjedőben vannak a nyelvi iparban és a nyelvi közvetítői piacon egyaránt. Az új technológiák által meghatározott találmányok és eszközök rendszeresen megjelennek a munkakörnyezetünkben. A legtöbb fejlesztő tevékenységének a célja, hogy a teljesen automatizált fordítás és tolmácsolás szintjére jussanak el.

A technológiai fejlödés hatása a fordítási piacon elöbb és nagyobb mértékben volt érezhető, mint a tolmácsolási piacon. Ennek egyik oka az lehet, hogy a fordítási piac méretét tekintve nagyobb, valamint, hogy a tevékenységek szélesebb skáláját öleli fel. Mindez azt jelenti, hogy nagyobb igény mutatkozik mind az ember által készített mind a gépi fordításokra. Egy másik ok lehet, hogy a tolmácsolás automatizálásához számos olyan, valós idejü tényezőt kell figyelembe venni, ame-

\footnotetext{
${ }^{5}$ AI Interpreter Fail at China Summit Sparks Debate about Future of Profession https://slator.com/features/ai-interpreter-fail-at-china-summit-sparks-debate-about-future-of-profession/
} 
lyek a fordításkor nem jelennek meg. A beszédek tolmácsolása valós időben történik, a tolmácsok ún. „online” módban dolgoznak, és a célnyelvi beszédet azonnal hozzák létre. Ez azt is jelenti, hogy az elhangzást megelőzően nincs lehetőség előszerkesztésre, mint ahogy azt követően sincs lehetőség utószerkesztésre.

Ami a tolmácsolást támogató terminológiamenedzsment szoftvereket illeti, elmondható, hogy a tolmácsok nem igazán mutatnak hajlandóságot arra, hogy ilyen eszközöket használjanak. Ez részben annak tudható be, hogy a tolmácsképzés középpontjában elsősorban a hivatásos tolmácsolás kommunikatív és kognitív aspektusaira álltak, és arra készítik fel a leendő tolmácsokat, hogy saját erőforrásaikra támaszkodjanak a tolmácsolás megbízás során. Mindazonáltal elmondható, hogy a modern tolmácsképzési programoknak része az új technológiák használata a tolmácsolás során (Riccardi et al. 2019; EMCI Core Curriculum). Egy másik ok pedig abban keresendö, hogy a tolmácsolás során a tolmácsolási módtól függetlenül a tolmácsokra nehezedő kognitív teher már alapjában véve nagy. A digitális kabinban tolmácsolási terminológiamenedzsment szoftver használata feltehetőleg egy további kognitív erőfeszítést jelentene, amihez a tolmácsok nincsnek hozzászokva.

Végezetül elmondható, hogy jóllehet a technológiai fejlődés az egész világot és egész iparágakat felbolygatott, még mindig vannak olyan szakmák, ahol emberekre van és belátható időn belül lesz is szükség. Ezek olyan szakmák, amelyek különleges és egyedülálló készségeket igényelnek. Marr (2019) a jövő munkavállalói számára tíz elengedhetetlen készséget sorol fel, köztük olyanokat, mint a kreativitás, az érzelmi intelligencia, analitikus (kritikus) gondolkodás, értékelés és döntéshozatal, interperszonális kommunikációs készségek, sokszínűség és kulturális intelligencia. Jó hír a szakmánk számára, hogy vannak olyan fordítási területek, például a müfordítás és az audiovizuális fordítás, valamint tolmácsolási területek, mint például a közösségi, bírósági vagy a konferenciatolmácsolás, amelyek elvégzéséhez ezekből a képességekből számos szükséges.

\section{Irodalom}

Basalamah, S. 2001. The Thorn of Translation in the Side of the Law. Towards Ethical Copyright and Translation Rights. The Translator Vol.7. No. 2. 155-167.

Bar-Hillel, Y. 1951. The present state of research on mechanical translation. American Documentation Vol. 2. No. 4. 229-237.

Bassnett, S. 1991 Translation Studies. London: Routledge.

Braun, S. 2015. Remote interpreting. In: Mikkelson, H., Jourdenais, R. (eds) Routledge Handbook of Interpreting. London: Routledge. 352-367.

Corina, D. P., Vaid, J. 1994. Lateralisation for Shadowing Words versus Signs: A Study of ASL-English Interpreters. In: Lambert, S., Moser-Mercer, B. (eds) Bridging the Gap.

Amsterdam/Philadelphia: John Benjamins Publishing Company. 237-248.

Costa, H., Corpas Pastor, G., Durán-Muñoz, I. 2014. Technology-assisted interpreting. Multilingual Vol. 25. No. 3. 27-32.

Cronin, M. 2013. Translation in the Digital Age. London \& New York: Routledge. 
Fantinuoli, C. 2017a. Computer-assisted interpretation: challenges and future perspectives. In: Durán-Muñoz, I., Corpas Pastor, G. (eds) Trends in e-tools and resources for translators and interpreters. Leiden: Brill.

Felekné Csizmazia E. 2014. A fordítás és a tolmácsolás határán. A blattolás kutatása. Fordítástudomány 16. évf. 2. szám. 24-36.

Gile, D. 2009. Basic Concepts and Models for Interpreter and Translator Training, revised edition. Amsterdam: John Benjamins.

Hepp, A. 2015. Transcultural Communication. Chichester: Wiley Blackwell.

Horváth, I. 2013. Bírósági tolmácsolás. Budapest: ELTE Eötvös Kiadó.

Hutchins, W. J. 1986. Machine Translation: Past, Present, Future. New York: Wiley \& Sons.

Katan, D. 2000 Translating Cultures. An Introduction for Translators, Interpreters and Mediators. Manchester: St. Jerome Publishing.

Lawson, V. (ed.) 1981. Practical experience of machine translation. Proceedings of a conference. London 5-6 November 1981. Amsterdam, New York, Oxford: North-Holland Publishing Company. 39-44.

Moser-Mercer, B. 2005. Remote interpreting: Issues of multi-sensory integration in a multilingual task. Meta Vol. 50. No. 2. 727-738.

Mouzourakis, P. 2010. Remote interpreting - A technical perspective on recent experiments. Interpreting Vol. 8. No. 1. 45-66.

Parkin, Ch. 2010. La traduction à vue - une forme hybride entre l'interprétation et la traduction écrite, In: Iliescu, M., Siller-Runggaldier, H., Danler, P. (eds) XXVe CILPR Congrès International de Linguistique et de Philologie Romanes Innsbruck, 3-8 septembre 2007. Berlin, New York: de Gruyter. 613-622.

Riccardi, A., Čeňková, I., Tryuk, M., Maček, A., Pelea, A. (Projects Committee, EMCI Consortium) 2019. Survey of the Use of New Technologies in Conference Interpreting Courses. In: Rodríguez Melchor, D. M., Horváth, I., Ferguson, K. (eds) The Role of Technology in Conference Interpreter Training. Oxford: Peter Lang (in press)

Sager, J. C. 1994. Language Engineering and Translation: Consequences of automation. Amsterdam: John Benjamins Publishing Company.

Samovar, L. A., Porter, R. E. 1997. Intercultural Communication. Belmont: Wadsworth Publishing Company.

Schippel, L. 2012. Between Consensus and the Dissolution of Boundaries: On the Transculturality of Communicative Action. Berlin: Frank \& Timme.

Somers, H. L. 1998. Machine Translation, applications. In: Baker, M. (ed.) Routledge Encyclopaedia of Translation Studies. London: Routledge. 136-140.

Vauquois, B. 1976. Automatic translation - A survey of different approaches. Statistical Methods in Linguistics 1976: 127-135.

Venuti, L. 1998. The Scandals of Translation: Towards a Practical Approach. London and New York: Routledge. 


\section{Online elérhető hivatkozások}

Ábrányi, H. 2015. Fordítási környezetek. In: I. Horváth (szerk.). A modern forditó és tolmács. Budapest: ELTE Eötvös Kiadó, 147-161. (utolsó megtekintés: 2019. december 28.) http://www.eltereader.hu/media/2017/01/Horvath_Modern-ford_READER.pdf

European Commission, DG SCIC. 2019. Interpreting Platforms. Consolidated results and Test Analysis. https://ec.europa.eu/education/knowledge-centre-interpretation/sites/ kci/files/interpreting_platforms___consolidated_test_results_and_analysis_-_def. pdf (utolsó megtekintés: 2019. december 28.)

EMCI Core Curriculum. 2017. https://www.emcinterpreting.org/course-structure (2019. december 28.)

EMT Competence Framework - 2017. https:/ec.europa.eu/info/sites/info/files/emt_competence_fwk_2017_en_web.pdf (utolsó megtekintés: 2019. december 28.)

Esteves, L. M. R. 2005. Intellectual Property and Copyright: The case of translators. Translation Journal Vol. 9. No. 3. https://translationjournal.net/journal/33copyright. htm (utolsó megtekintés: 2019. december 28.)

Fantinuoli, C. 2017b. Computer-assisted preparation in conference interpreting. Translation \& Interpreting. 2(9). http://www.trans-int.org/index.php/transint/article/view/565 (utolsó megtekintés: 2019. december 28.)

Gambier, Y. (EMT Expert Group). 2009. Competences for professional translators, experts in multilingual and multimedia communication. https://ec.europa.eu/info/sites/ info/files/emt_competences_translators_en.pdf(utolsó megtekintés: 2019. december 28.)

Horváth, I. 2015a. Előszó. In: I. Horváth (szerk.). A modern forditó és tolmács. Budapest: ELTE Eötvös Kiadó, 7-8. (utolsó megtekintés: 2019. december 28.) http://www.eltereader.hu/media/2017/01/Horvath Modern-ford READER.pdf

Horváth, I. 2015b. Információ és kommunikációs technológiák a tolmácsolásban és gépi tolmácsolás. In: I. Horváth (szerk.). A modern forditó és tolmács. Budapest: ELTE Eötvös Kiadó, 161-170. (utolsó megtekintés: 2019. december 28.) http://www.eltereader.hu/media/2017/01/Horvath Modern-ford READER.pdf

Horváth, I. (szerk.) 2015c. A modern forditó és tolmács. Budapest: ELTE Eötvös Kiadó, 7-8. (utolsó megtekintés: 2019. december 28.) http://www.eltereader.hu/media/2017/01/Horvath Modern-ford READER.pdf

Marr, B. 2019. The 10 Vital Skills You Will Need for the Future of Work. https://www. forbes.com/sites/bernardmarr/2019/04/29/the-10-vital-skills-you-will-need-for-thefuture-of-work/\#2825d6893f5b (utolsó megtekintés: 2019. december 28.)

Mileto, F. 2011. From Computer Assisted Translation to Human Assisted Translation. Tralogy - Les 3 et 4 mars 2011 - Session 3 - Machine and Human Translation: Finding the Fit? / TA et Biotraduction. http://lodel.irevues.inist.fr/tralogy/index. php?id=217\& format=print (utolsó megtekintés: 2019. december 28.)

Rinsche, A., Portera-Zanotti, N. 2009. The Size of the Language Industry in the EU. https:// publications.europa.eu/en/publication-detail/-/publication/9a68479a-1c07-4c438d1a-8d49782c0808 (utolsó megtekintés: 2019. december 28.)

Rummel, D. 2019. Beyond MT? A few premature reflections on the use of MT in translation. TAUS Global Content Summit Amsterdam, 6 March 2019. https://www.slideshare.net/TAUS/taus-global-content-summit-amsterdam-2019-beyond-mt-a-few- 
premature-reflections-on-the-use-of-ai-in-translation-by-dieter-rummel-head-of-informatics-dgt-european-commission (utolsó megtekintés: 2019. december 28.)

Taravella, A., Villeneuve, A. O. 2013. Acknowledging the needs of computer-assisted translation tools users: the human perspective in human-machine translation. Jostrans Vol. 19. http://www.jostrans.org/issue19/art_taravella.pdf (utolsó megtekintés: 2019. december 28.)

The Language Services Market: 2018. Annual Review of the Services and Technology Industry That Supports Translation, Localization, and Interpreting. https://insights. csa-research.com/reportaction/48585/Marketing (utolsó megtekintés: 2019. december 28.)

Translation and intellectual property rights. Final report-Study. 2014. https://publications.europa.eu/en/publication-detail/-/publication/e079e290-e250-482d-9d4f-dae566ba67ff/language-en (utolsó megtekintés: 2019. december 28.)

Varga Á. 2015. Gépi fordítás. In: Horváth I. (szerk.). A modern fordító és tolmács. Budapest: ELTE Eötvös Kiadó, 135-146. (utolsó megtekintés: 2019. december 28.) http:// www.eltereader.hu/media/2017/01/Horvath_Modern-ford_READER.pdf

2019 Language Industry Survey - Expectations and Concerns of the European Language Industry. https://ec.europa.eu/info/sites/info/files/2019_language_industry_survey_ report.pdf (utolsó megtekintés: 2019. december 28.) 